\section{EDUCATIONAL EFFECTIVENESS DF THE 5E MODEL FDR SCIENTIFIC ACHIEVEMENT DF STUDENTS WITH HEARING IMPAIRMENT}

\section{Zahida Parveen}

\section{Introduction}

Cognitive abilities are pre-requisites for learning science rather than hearing ability. The importance is to what extent impairment in hearing ability affects cognitive development, or intellectual abilities. Leading researchers have concluded that deaf people are not intellectually deficient (Moores, 1979); they have the same range of cognitive ability as other students (Bursuck \& Friend, 1996; Paul \& Jackson, 1993). According to Rittehouse and Spiro (as cited by Moores, 1979), deaf people exhibit the same level of intelligence as normal hearing people. Thus, there are no reasons why science cannot be taught to these students. Hundreds of examples are found in the literature about deaf people who have made their careers in science education. Science education expands the experiential background for students with disabilities who have limited experiences (Patton \& Andre, 1989) and is recommended as the most valuable subject for students with sensory and physical disabilities (Mastropieri, Scruggs, Boon, \& Carter, 2001; Atwood \& Oldham, 1985; Hadary, Hadary \& Cohen, 1978; Linn \& Thier, 1975).

Difficulties exist due to hearing loss in communication and learning, but this does not mean that teachers should not make efforts to teach science to these students. The teaching methodology can encourage and motivate these students towards choosing a career. If emphasis is placed on multisensory active learning and the use of different strategies based on teaching problem solving, a significant rise in the achievement of science among these children can be observed (Luckner \& Carter, 2001). However, the lack of teacher training of special educators in science teaching is a contributing factor for low scientific achievement of students with hearing impairment (Malik, 2014). Elementary teachers do lack practical exposure to science, which may lead to their limited knowledge about science (Atwater, Gardner \& Knight, 1991). Special education teachers report that most of the time, science is not taught and if taught, less time is allocated to students with disabilities as compared to general education science students (Patton, Polloway, \& Cronin, 1990). Further, $42 \%$ of special education teachers are not trained for teaching science

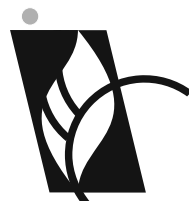

J O U R N A L

$\mathrm{OF} \bullet \mathrm{B}$ A L T I C

$S$ C I E N C E

E DUCATION

ISSN 1648-3898 /Print/ ISSN 2538-7138 /Online/

Abstract. This experimental research aimed to find the effectiveness of the $5 E$ model of education for achievement in science among students with hearing impairment at the elementary level. An instructional package was developed following the 5E model for one unit from a science subject in grade VIII. A science test was developed by the researcher to test the achievement of students of grade VIII with hearing impairment. This test was validated by experts, pilot tested, subjected to item analysis and the reliability of the test was calculated. The test with 38 items was used as a pre-test and post-test during the study. Thirty-four students of grade VIII were selected from a school and were random assigned to two groups. One group was randomly assigned as the experimental group and the other served as the control group. The research followed a pre-test-post-test control group design. The performance of both groups was compared to evaluate the effectiveness of instructions based on the $5 E$ model. A significant improvement was found in the performance of the experimental group as compared to the control group. It was concluded that hearing impaired children can perform better in science if they are taught through approaches promoting construction of knowledge, such as in the 5E model.

Keywords: hearing impairment, scientific achievement, 5E model.

Zahida Parveen University of Education, Pakistan 
and $38 \%$ of special children do not receive any science instruction. Cawley (1994) highlights the issues in science education for students with disabilities. According to him, special educators have little experience of science, while science teachers have little knowledge of adaptations for disabilities. This suggests a need to train science teachers with sufficient knowledge of teaching deaf students.

Constructivist and activity-based teaching approaches are found to better enable the acquiring of science concepts among students with hearing impairment (Barman, (1991). Hands on experiences are beneficial for these students, as is the case for students without disabilities, to develop understanding of complex processes of science. According to Chira (1990), deaf students can be taught science through active explorations. Lang (1995) also emphasized the use of such instructional strategies to cognitively engage deaf students. Research evidence supports the use of a three-phase learning cycle, based on active learning, in science instruction to students with hearing impairment (Charles \& Jill, 1991).

The 5E model, based on a learning cycle of five phases, is an innovation resulted from studies at the Centre of Biological Sciences Curriculum Studies (BSCS, 1997). The $5 \mathrm{E}$ model is viewed from a conceptual change (Volkmann, Brown, West, Lankford, \& Abell, 2009) and inquiry learning perspectives (Wilson, Taylor, Kowalski, \& Carlson, 2010). The sequence within the model for the teaching process is applicable in the development of programs, units and lessons. The $5 \mathrm{E}$ instructional model consists of five phases:

Engage. The teacher or a curriculum task accesses the learners' prior knowledge and helps learners become engaged in a new concept through the use of short activities that promote curiosity and elicit prior knowledge.

Explore. Exploration experiences provide students with a common base of activities within which current concepts (i.e., misconceptions), processes, and skills are identified and conceptual change is facilitated.

Explain. The explanation phase focuses students' attention on a particular aspect of their engagement and exploration experiences and provides opportunities to demonstrate their conceptual understanding, process skills, or behaviors.

Elaborate. Teachers challenge and extend students' conceptual understanding and skills.

Evaluate. The evaluation phase encourages students to assess their understanding and abilities and provides opportunities for teachers to evaluate student progress toward achieving the educational objectives" (p. 1)

This model is found to improve achievement in science among students in general. Ozsevgec (2006) investigated the effectiveness of guided materials about "Force and Motion" for elementary students, based on the $5 \mathrm{E}$ model. He concludes that guided material increases the level of academic success of elementary students and their attitudes become more positive and retainable. Hirca, Çalik, and Seven (2011) investigate the effect of instruction, based on the $5 \mathrm{E}$ model, on conceptual change. They conclude that instruction, based on the 5E model, is more effective for students to comprehend related concepts and in overcoming their own alternative conception, as compared to a traditional one. Caprico (1994) reports student gains when taught through a constructivist methodology. Brad (2000) compares instruction based on a constructivist approach with a teacher centered method and found a higher degree of academic achievement in favor of the student-centered approach. Positive outcomes using 5E activities are also reported by Moseley, Reinke, and Bookout (2002), Boddy, Watson, and Aubsson (2003), Einsenkraft (2003), Clark (2003), Evans (2004), Newby (2004), Akar (2005), Cardak, Dikmenli \& Saritas (2008) as well as Wilson, Taylor, Kowalski \& Carlson (2010).

Deaf students can perform equally as well as their counterparts with the required adaptation and appropriate strategies used by teachers. Moores (1987), quoting an example of a study by Karchmer and Belmont on short term memory, indicates that deaf students performed at a lower level than hearing students. However, after teaching through appropriate strategies to deaf subjects, they then find that deaf children can function at the same level as hearing children. They conclude that the lower initial performance of deaf students is not because of a cognitive deficit, but through not knowing which strategy to apply. Research related to learning styles and cognition of deaf students show that no differences are found among students with and without hearing. Lang (1995) concludes from the results of a study, based on Grasha-Reichmann Student Learning Styles Scales, those adolescents with and without deafness have similar learning styles. This study also indicates that deaf adolescents value clarity, organization, and structure.

There are many research studies supporting the use of constructivist approaches with hearing impaired students. Elefant (1980), in conducting an experiment on deaf students implementing an Inquiry Development Program, concludes that deaf students are successful in acquiring inquiry skills. Boyd and George (1973) also observe higher scores for deaf group using hands-on activities. Lang, Stinson, Basile, Kavanagh, and Liu (1999) conclude that higher participation of deaf students in activities leads to higher grades. In a study by Quinsland 
(1986), deaf students' learning is enhanced by an experiential activity, where they act out the different parts of the human heart. The factual learning by the students is significantly better than that of a control group which are guided to learn the same material through a traditional lecture. Akynoglu and Tandogan (2007) determine that the use of active learning models enhances the academic achievement and develops positive attitudes towards the learning of science.

Brown et al., (2002) designed a project 'Classroom of the Sea' (COS). From their study, they concluded that a constructivist environment was helpful in increasing deaf students' knowledge, attitude, behavior (KAB) and selfefficacy related to science. Bybee and Hendricks (1972) worked on developing science concepts among preschool deaf students using materials from the Science Curriculum Improvement Study (SCIS). The basic teaching sequence of SCIS (exploration, invention, and concept application) was used with adaptations made for deaf in the teaching method. The study reported a positive gain in achievement. Sunal and Sunal (1982) reported positive gains in the achievement of science among students with hearing impairment using adapted information from the Houghton Mifflin Science series to incorporate a multi-sensory approach to teaching science.

Achievement by Pakistani students with hearing impairment is underestimated in terms of their learning. Classroom learning of students with hearing impairment is inadequate (Noreen \& Aziz, 2000). Science education encourages children to think imaginatively and logically, but only if the concepts are acquired accurately. It is found in a study that students with hearing impairment acquire weak concepts of science as compared to their counterparts (Nazir \& Iram, 2001). Similarly, Bashir \& Akram (1998) find that achievement of students with hearing impairment in Science, Social Studies and Mathematics is lower than their counterparts. In another study of general science concepts, Shah \& Anjum (2009) find misconceptions among hearing impaired children regarding basic scientific concepts.

Afzal \& Naz (1998) found the possible reasons for the low achievement of students with hearing impairment in science including the inability of the teachers to communicate effectively with students and a lack of application of various teaching methods in the classrooms. Iqbal and Sharif (2006) conducted a study of problems faced by children with hearing impairment in learning of science at VIII grade. They concluded that the syllabus of science at VIII grade was not fulfilling the modern demands and students were not satisfied with the teaching methods of science teachers. It was found that the students'view was that their science curriculum was lacking in the development of scientific thinking, problem solving and observation skills. Moreover, this research recommended the use of laboratory and hands on activities to enhance scientific achievement among students with hearing impairment.

In Pakistan, science teachers of students with hearing impairment at elementary level have set low profiles for these students about science learning (Malik, 2014). A major problem is observed in schools with the appointing of special education teachers as science subject teachers of HIC. These teachers lack subject knowledge as well as being unaware of specific teaching methods for science. This is a result of the thinking that, in Pakistan, students with hearing impairment are not to be provided with the option to opt for science beyond elementary level. The Board of Intermediate and Secondary Education (BISE) offers tailoring, embroidery, type writing, carpet weaving, rug weaving, drawing, bakery, hosiery, computer science and physical education. BISE specifies that achievements of students with hearing impairment are to be assessed for knowledge, comprehension and application levels (Board of Intermediate and Secondary Education Lahore, 2010). It is a fact that their inability to listen has a significant impact on their learning, but research shows that the cognition of children with hearing impairment is comparable with their peers without hearing loss. They may face difficulties in learning science due to poor hearing, inappropriate instruction, teachers' unfriendly attitude and parents holding a low-profile set. Schools are not providing necessary support to science teachers to teach science to children with hearing impairment in an effective way. It is also a possible reason why teachers are not ready to accept the challenge of teaching science to children with hearing impairment. According to Fontana \& Lari (2001), a large majority of head teachers (74\%) in Pakistan give lowest priority to science studies in the curriculum for students with special needs. They further highlight the need for research in experimenting with teaching methods and learning approaches.

As the $5 \mathrm{E}$ model is found to increase the scientific achievement among general students, it is predicted to be appropriate for disadvantaged students. Hence, in this research, an intervention, based on 5E model, is developed to evaluate its effect on science achievement among students with hearing impairment. Further, this research is delimited to only the first three levels (Knowledge, Comprehension and Application) of cognitive domain, as in Pakistan, BISE (2010) limits assessment to these levels for students with hearing impairment at elementary level. Additionally, it's effectiveness for both genders are explored. 


\section{Null Hypotheses}

The research was conducted to test the following hypothesis:

1. There was no significant difference in achievement in science between students with hearing impairment receiving instructions based on the $5 \mathrm{E}$ model and those receiving regular classroom instructions.

2. There was no significant difference in achievement in science between male and female students with hearing impairment receiving instructions based on $5 \mathrm{E}$ model of learning and those taught through regular classroom instructions

3. There is no significant difference in achievement scores of the control and experimental group on the basis of components of the cognitive domain.

\section{Methodology of Research}

\section{General Background}

The target population of this research was students of grade VIII with hearing impairment, studying in Lahore schools. Children with hearing impairment were taught in a separate school system in Pakistan. They had low scientific literacy skills as compared to their counterparts (Shaukat \& Rubab, 2007). Their potential for learning was underestimated by the school administrations and science teachers (Shehbaz \& Batool, 2008). Therefore, science was not taught to children with hearing impairment beyond elementary level. The scope of this research was to evaluate the learning of science among deaf students when a $5 \mathrm{E}$ instructional model was used instead of the traditional lecture method. This research covered a period of ten months in total, including development of achievement test and intervention, and conduction of experiment. However, the experiment based on $5 \mathrm{E}$ model covered twenty-four class sessions of forty minutes each across six weeks. The study followed pre-test post-test control group design.

\section{Sample}

Thirty-four students with hearing impairment of grade VIII from Hamza Foundation Academy for the Deaf were selected for the purpose of the research. The age of these students ranged between middle and late adolescence. The probable reason for this variation in age within the grade was late admission of some students in schools.

\section{Criteria for the Selection of Academy}

The Hamza Foundation Academy for the Deaf was selected for this study for the following reasons.

1. An appropriate number of students studying in Class VIII.

2. An appropriate number of female students in class VIII.

3. The school administration was eager to cooperate in the research.

4. All relevant data of students were attainable.

Thirty-four students of $8^{\text {th }}$ class were selected for the research. These students were divided into three sections within the school, but the researcher divided them into two groups for science instructions. A list of students from the class teachers was obtained and an ID code was assigned to each student. These students were divided into two groups of seventeen students through random assignment. One group was randomly selected as the control group. This group received regular classroom instructions. The other group was selected as the experimental group. This group received specially designed instructions based on the $5 \mathrm{E}$ model. For this purpose, a science teacher from the same academy was trained through few sessions and provided with a set of developed intervention materials by the researcher.

\section{Instrument and Procedures}

1. Achievement Test

One chapter "classification of organisms" was selected from the syllabus of class VIII, and, for this, a test was developed to measure the achievement of students with hearing impairment. In addition, the researcher personally 
ISSN 1648-3898/Print/_ EDUCATILNAL EFFECTIVENESS QF THE 5E MLDEL FIR SCIENTIFIC ACHIEVEMENT QF

visited the schools to discuss the content for the study with the science teachers. This was based on the textbook from the Punjab text-book board for teaching science to grade VIII as all schools followed the same textbook.

The major topic of "Classification of organisms" was selected on the following basis:

1. Most of the teachers agreed to use this topic.

2. The topic of classification is seen as a base for building higher concepts indicated in the syllabus.

A table of specifications was developed consisting on six sub-topics, using Bloom's taxonomy for the cognitive domain, and forty-three test items were constructed. This test was presented to science education experts in constructivist approaches and education for the deaf. Their suggestions were incorporated in modifications to the test. Further, this test was pilot tested with 49 students with hearing impairment from three schools of Lahore and then subjected to item analysis. After expert validation and item analysis, the instrument was reduced to 38 items and was used as a pre-test and post-test during the study. The Cronbach alpha of the test was 0.83 .

\section{Development of Intervention}

A set of instructions were developed by the researcher, based on the $5 \mathrm{E}$ model and validated by an expert of constructivist approaches. One lesson was pilot tested with a group of fourteen students with hearing impairment in a Goverment Secondary School of Special Education for the Hearing Impaired Children (Boys). These students were not included in the final study. One lesson for each sub-topic (six) from the unit "Classification of organisms" was developed according to the phases of the $5 \mathrm{E}$ instructional model. Each lesson consisted of Instructional Objectives, Content Focus, Overview, Key words, Required Materials, Classroom Layout, Instructional Procedure (5Es) and Closure.

\section{Conduction of Experimentation}

The control group was taught by its science teacher through a traditional lecture method, involving direct teaching, question and answer technique, drill and practice technique, and using total communication with the hearing impaired. The experimental group was taught using the $5 \mathrm{E}$ model of instruction. A 40 minutes class period was specified for each day for both groups. The treatment was given to the experimental group for six weeks. The school schedule was followed in the research for time and day allocation. There were four class periods per week for science subject. One lesson for each sub-topic was prepared. There was no time boundary for the completion of a lesson. Consumption of class periods for each lesson was kept flexible according to hearing disability of students because once the lessons were developed according to $5 \mathrm{E}$ model; it was easy to adapt already planned lessons for time and other changes. In this way, six sub-topics were covered in twenty-four class periods. The science test, with thirty-eight items developed by the researcher, was conducted with both the control group and experimental group prior to the treatment. After the treatment, the same test was administered as a post-test to both groups.

\section{Results of Research}

The scores of students on the achievement test were analyzed to find differences among the control group and experimental group on the pre-test, the post-test and gained scores. An independent sample t- test was carried out to find the significance of these differences.

Table 1. Comparison of control group and experimental group on pre-test, post-test and gain scores.

\begin{tabular}{ccccc}
\hline Group & & Pre-test & Post-test & Gain scores \\
\hline Control & $N=17$ & & 55.12 & 18.24 \\
& $M$ & 36.88 & 19.36 & \\
& $S D$ & 15.93 & & \\
\hline & $N=17$ & & & \\
\hline Experimental & $M$ & 35.18 & 13.00 & 35.82 \\
\hline & $S D$ & 13.18 & 9.52
\end{tabular}




\begin{tabular}{|c|c|c|c|c|}
\hline Group & & Pre-test & Post-test & Gain scores \\
\hline & $M D$ & 1.70 & 15.88 & 17.58 \\
\hline & $t$-value & 0.34 & 82.78 & 6.27 \\
\hline & $p$ value & 0.73 & .009 & .0001 \\
\hline
\end{tabular}

Table 1indicates the results of an independent sample t-test on pre-test, post-test and gain scores for the control group and the experimental group. Results show that there were no significant differences among the control group and the experimental group on pre-test scores. However, significant difference is observed between post-test scores and gain scores of the control groups and the experimental group.

\section{Comparison Based on Gender}

Table 2. Gender wise comparison of control group and experimental group on pre-test, post-test and gain score.

\begin{tabular}{|c|c|c|c|c|}
\hline Group & & Pre-test & Post-test & Gain score \\
\hline \multirow[t]{3}{*}{ Girls control } & $N=5$ & & & \\
\hline & $M$ & 41.20 & 57.40 & 16.20 \\
\hline & $S D$ & 22.81 & 24.55 & 4.19 \\
\hline \multirow[t]{6}{*}{ Girls Exp } & $N=6$ & & & \\
\hline & $M$ & 40.50 & 74.00 & 33.50 \\
\hline & $S D$ & 18.16 & 14.64 & 11.34 \\
\hline & $M D$ & 0.70 & 16.60 & 17.30 \\
\hline & $T$ & 0.05 & 1.39 & 3.15 \\
\hline & $p$ & .95 & .19 & .01 \\
\hline \multirow[t]{3}{*}{ Boys Control } & $N=12$ & & & \\
\hline & $M$ & 35.08 & 54.17 & 19.08 \\
\hline & $S D$ & 12.96 & 17.96 & 7.11 \\
\hline \multirow[t]{6}{*}{ Boys Exp } & $N=11$ & & & \\
\hline & $M$ & 32.27 & 69.36 & 37.09 \\
\hline & $S D$ & 9.31 & 13.07 & 8.71 \\
\hline & $M D$ & 2.81 & 15.19 & 18.01 \\
\hline & $T$ & 0.59 & 2.30 & 5.45 \\
\hline & $p$ & .56 & .03 & .0001 \\
\hline
\end{tabular}

Results showed that there was a significant difference in gain scores of girls of both groups and boys of both, control and experimental groups (Table 2). Girls and boys in the control group and experimental group performed equally on pre-test. Boys in experimental group improved significantly on the post-test as compared to boys in the control group, while this difference was not significant for girls of both groups on the post-test.

\section{Comparison of Achievement Scores by Levels of Cognitive Domain}

Students' performance for each Bloom's level of cognitive domain on the achievement test was analyzed to find difference in performance by the control group and the experimental group over different component of the test. An independent sample t-test was used to find the differences. 
Table 3. Comparison of control group and experimental group performance on levels of cognitive domain on the achievement test.

\begin{tabular}{|c|c|c|c|c|c|c|c|}
\hline \multirow[t]{2}{*}{ Group } & & \multicolumn{3}{|c|}{ Pre-test } & \multicolumn{3}{|c|}{ Post-test } \\
\hline & & Know & Comp & App & Know & Comp & App \\
\hline \multirow[t]{3}{*}{ Control } & $N=17$ & & & & & & \\
\hline & $M$ & 15.24 & 12.59 & 9.24 & 22.41 & 19.24 & 13.71 \\
\hline & $S D$ & 7.00 & 5.07 & 6.67 & 8.04 & 6.08 & 6.86 \\
\hline \multirow[t]{6}{*}{ Experimental } & $N$ & & & & & & \\
\hline & $M$ & 14.71 & 12.29 & 8.53 & 22.65 & 24.00 & 24.35 \\
\hline & $S D$ & 6.88 & 5.37 & 3.31 & 5.76 & 4.07 & 6.35 \\
\hline & $M D$ & 0.53 & 0.30 & 0.71 & 0.24 & 3.76 & 10.64 \\
\hline & $T$ & 0.22 & 0.16 & 0.39 & 0.09 & 2.68 & 4.69 \\
\hline & $p$ & .82 & .87 & .70 & .92 & .01 & .0001 \\
\hline
\end{tabular}

Before the intervention, the control group and experimental group students performed equally on the three cognitive levels (knowledge, comprehension, and application), while after intervention the experimental group showed good performance on comprehension and application component of cognitive domain as compared to performance of the control group (Table 3). It was concluded that 5E instruction improved comprehension and application abilities. Achievement in the knowledge component was the same in the control group and experimental group after the different treatments.

\section{Discussion}

The research was designed to assess the effectiveness of an inquiry oriented, $5 \mathrm{E}$ model on achievement in science among students with hearing impairment. Findings indicated that students who received instructions based on the $5 \mathrm{E}$ model gained a significant higher achievement in science as compared to their counterparts who were taught through a lecture method. The results of this study were consistent with earlier studies conducted on students with hearing impairment with reference to inquiry based instructions (Grant, Rosenstein \& Knight, 1975, Hadary, Haushatter, \& Rosenberg, 1976, Boyed \& George, 1973). The effectiveness of instruction, based on the 5E model, was evident from the literature that supported the findings of the present study (Ozsevgec, 2006; Ozdilex \& Ozkan, 2009; Ergin, Kanli \& Unsal, 2008; Wilson et al. 2010).

Instruction, based on the 5E model, was equally applicable for girls and boys in the experimental group. No differences in achievement were found among girls and boys receiving the intervention. Boys in the experimental group performed better on the post-test as compared with the control group boys while the same result was given by the girls. These findings contrasted with the study by Zaleta (2014), who studied the impact of gender on science process skills of general students. He found that girls gained higher scores than boys when taught through an inquiry curriculum.

The intervention proved to be more effective for application and comprehension components of the cognitive domain, although no difference was found between students of the control group and experimental group on the knowledge component of the cognitive domain, where both groups gained almost equally. This finding was supported by research by Mao, Chang, and Barufaldi (1998). They found in their experimental study that inquiry group students performed better on higher order skills (comprehension and application) than knowledge retention, when compared with their counterparts in a control group.

The pilot instructional testing session, prior to the research, was very exciting for the researcher, because it provided the courage to complete the intervention. The students with hearing impairment were found to be very enthusiastic throughout the study as they actively participated in activities. On the verbal request of the head of the school wing, a brief session, after the study, was conducted by the researcher for the science teachers of the academy to give them some understanding of this constructivist approach. This phase was really an enriching 
and exciting experience. It was felt during the study that teachers were willing to teach using methods other than traditional one if the administration asked them to do so. Although they were still reluctant to use inquiry in their daily lessons, they liked the approach.

The willingness of teachers to use teaching methods, based on inquiry (like 5E), indicates a change in their perception and attitude towards science learning among students with hearing impairment. Studies focusing on the effects of inquiry oriented teaching methods on attitudinal changes among teachers of hearing impaired students are recommended for future research.

\section{Conclusions}

The present research concludes that the students receiving inquiry-based instructions, based on the approach associated with the $5 \mathrm{E}$ model, performed better based on the post-test and their gain scores are significantly higher when compared with scores by the control group. The null hypotheses are therefore rejected. This research strengthens the idea that where inquiry instruction can be successfully implemented in science classrooms of students with hearing impairment, they can achieve at a higher level. These findings may also raise teacher's impression about the capabilities of hearing impaired students when the focus is on teaching methodologies which can enhance scientific achievement. Using a teaching approach based on the $5 \mathrm{E}$ model is shown to be effective for hearing impaired students.

This research has implications for curriculum developers in Pakistan to reset the subject options available for the students with hearing impairment, after the elementary level, according to their potential for learning. Noting the student gains using a more inquiry-based teaching approach suggest that offering science beyond the elementary level can be strongly recommended. To further educational developments of hearing impaired students this study recommends promoting teacher training programs for science teachers of the deaf, with emphasis on the use of inquiry method, highly equipped science labs for hearing impaired institutes and appointment of teachers with a master's degree in science as science teachers in schools for the hearing impaired. Further, researchers in science education need to explore other more effective strategies to enhance scientific achievement among hearing impaired students.

\section{References}

Afzal, A., \& Naz, M. (1998). A study of the problems faced by the teachers of hearing impaired children. (Unpublished master's thesis). University of the Punjab, Pakistan.

Akar, E. (2005). Effectiveness of 5 e learning cycle model on students' understanding of acid-base concepts. (Unpublished master's thesis). Retrieved from: http://etd.lib.metu.edu.tr/upload/12605747/index.pdf.

Akynoglu O., \& Tandogan, R.O. (2007). The effects of problem-based active learning in science education on students' academic achievement, attitude and concept learning. Eurasia Journal of Mathematics, Science \& Technology Education, 3 (1), 71-81 Retrieved from: http://www.ejmste.com/v3n1/EJMSTEv3n1_Akinoglu.pdf.

Atwater, M. M., Gardner, C., \& Knight, C. R. (1991).Beliefs and attitudes of urban primary teachers toward physical science and teaching physical science. Journal of Elementary Science Education, 3 (1), 3-12.

Atwood, R. K., \& Oldham, B. R. (1985). Teachers' perceptions of mainstreaming in an inquiry oriented elementary science program. Science Education, 69 (5), 619-624.doi: 10.1002/sce.3730690504.

Barman, C. R. (1991). Integrating science into the K-8 curriculum of deaf children. Final Report to the Indiana Commission for Higher Education. (67). Retrieved from: http://files.eric.ed.gov/fulltext/ED343779.pdf.

Bashir, R., \& Akram, F. (1998). The study of differential achievements of hearing impaired children and normal children of grade 5. (Unpublished mater's thesis). University of the Punjab, Pakistan.

Board of Intermediate and Secondary Education. (2010). Secondary school certificate: Important instructions. BISE Lahore.

BSCS, (1997). BSCS biology: A human approach (first edition). Dubuque, IA: Kendall/Hunt Publishing Company.

Boddy, N., Waston, K., \& Aubsson, P. (2003). A Trial of the Five Es: A referent model for constructivist teaching and learning. Research in Science Education, 33 (1), 27-42. Retrieved from: http://www.springerlink.com/content/r03926m2812212j7/fulltext.pdf.

Boyd, E., \& George, K. D. (1973). The effect of science inquiry on the abstract categorization behavior of deaf children. Journal of Research in Science Teaching, 10 (1), 91-99.

Brad, H. (2000). Teacher-centered Instruction versus Students-centered instruction. American School Board Journal, 1-5.

Brown, S. W., Babb, I., Johnson, P. R., Scheifele, P. M., Lang, H., Zheng, D., et al. (2002). Classroom of the Sea: Problem-based learning for the deaf. Proceedings of the International Conference on Computers in Education. Auckland, New Zealand: IEEE Press.

Bursuck, W. D., \& Friend, M. (1996). Including students with special needs: A practical guide for classroom teachers. London: Allyn \& Bacon. 
Bybee, R. W., \& Hendricks, P. A. (1972). Teaching science concepts to preschool deaf children to aid language development. Science Education, 56 (3), 303-310.doi: 10.1002/sce.3730560304.

Bybee, R. W., Taylor, J. A., Gardner, A., Scotter, P., Carlson Powell, J., Westbrook, A., et al. (2006). The BSCS 5E instructional model: origins and effectiveness. Retrieved from: http://science.education.nih.gov/houseofreps.nsf/b82d55fa138783c2852572c 9004f5566/\$FILE/Appendix\%20D.pdf.

Caprico, M.W. (1994). Easing into constructivism, connecting meaningful learning with students`experience. Journal of College Science Teaching, 23 (4), 210-212.

Cardak, O., Dikmenli, M., \& Saritas, O. (2008). Effect of 5E instructional model in student success in primary school $6^{\text {th }}$ year circulatory system topic. Asia-Pacific Forum on Science Learning and Teaching, (9) 2. Retrieved from: https://www.eduhk.hk/apfslt/ download/v9_issue2_files/cardak.pdf.

Cawley, J. F. (1994). Science for students with disabilities. Remedial and Special Education, 15 (2), 67.

Chira, S. (1990). Wherein balloons teach the learning process. Perspectives in Education and Deafness, 8 (4), 5-7.

Clark, 1. (2003). Soils ain't soils. Investigating: Australian Primary \& Junior Science Journal, 19 (4), 13-16.

Einsenkraft, A. (2003). Expanding the 5E Model. The Science Teacher, 70 (6), 56-59. Retrieved from http://www.its-about-time. com/iat/5e.pdf.

Elefant, E. F. (1980). Deaf children in an inquiry training program. The Volta Review, 82 (5), 271-279.

Ergin, I., Kanli, U., \& Unsal, Y. (2008). An example for the effect of 5E model on the academic success and attitude levels of students':"Inclined projectile motion". Journal of Turkish Science Education, 5 (3), 47-59. Retrieved from http://www.tused. org/internet/tused/archive/v5/i3/text/tusedv5i3s3.pdf.

Evans, C. (2004). Learning with inquiry minds: students are introduced to the unit on gas laws and properties of gases using the 5 E model. The Science Teacher, 71 (1), 4

Fontana, D., \& Lari, Z. (2001). The curriculum in special needs education in Pakistani schools. International Journal of Special Education, 16 (1). Retrieved from http://www.internationalsped.com/documents/fullissue161.doc.

Grant, W. D., Rosenstein, J., \& Knight, D. L. (1975). A project to determine the feasibility of BSCS's Me Now for hearing impaired students. American Annals of the Deaf, 120, 63-69.

Hadary, D. E., Hadary, S. H., \& Cohen, S. H. (1978). Laboratory science and art for blind, deaf, and emotionally disturbed children: A mainstreaming approach. Baltimore: University Park Press.

Hadary, D. E., Haushalter, R., \& Rosenberg, R. (1976). Breaking sound barriers for the deaf child. Science and Children, 14, 33.

Hirca, N., Çalik, M., \& Seven, S. (2011). Effects of guide materials based on 5E model on students' conceptual change and their attitudes towards physics: A case for 'work, power and energy unit. Journal of Turkish Science Education, 8 (1), 153-158. Retrieved from: http://www.tused.org/internet/tused/archive/v8/i1/text/tusedv8i1a8.pdf.

Iqbal, S., \& Sharif, A. (2006). A Study of problems faced by children with hearing impairment in learning science at VIII grade. (Unpublished master's thesis). University of the Punjab, Pakistan.

Lang, H. G. (1995). Best practices: Science education for deaf. Retrieved from http//deafed.net/PublishedDocs/LANGSciencelitreview5.doc.

Lang, H. G., Stinson, M. S., Basile, M., Kavanagh, F., \& Liu, Y. (1999). Learning styles of deaf college students and instructors' teaching emphases. Journal of Deaf Studies and Deaf Education, 4 (1), 16-27. Retrieved from: http://paperity.org/p/39750204/ learning-styles-of-deaf-college-students-and-instructors-teaching-emphases.

Linn, M. C., \& Thier, H. D. (1975). The effect of experiential science on development of logical thinking in children. Journal of Research in Science Teaching, 12 (1), 49-62.doi: 10.1002/tea.3660120108.

Luckner, J. L., \& Carter, K. (2001). Essential competencies for teaching students with hearing loss and additional disabilities. American Annals of the Deaf, 146 (1), 7-15.

Malik, A. (2014). A study of problems faced by students with hearing impairment in learning science. (Unpublished master's thesis). University of Management and Technology, Pakistan.

Mastropieri, M. A., Scruggs, T. E., Boon, R., \& Carter, K. B. (2001). Correlates of inquiry learning in science. Remedial and Special Education, 22 (3), 130-137.

Mao, S. L., Chang, C. Y., \& Barufaldi, J. P. (1998). Inquiry teaching and its effects on secondary-school students' learning of earth science concepts. Journal of Geoscience Education, 46, 363-367. Retrieved from: http://www.nagt.org/files/nagt/jge/abstracts/mao-chang-baruf.pdf.

Moores, D. F. (1979). Educating the deaf: Psychology, principles, and practices. Boston: Houghton Mifflin company.

Moores, D. F. (1987). Educating the deaf: Psychology, principles, and practices ( $3^{\text {rd }}$ ed.). Boston: Houghton Mifflin company.

Moseley, C., Reinke, K., \& Bookout, V. (2002). The effect of teaching outdoor environmental education on preservice teachers' attitudes toward self-efficacy and outcome expectancy. The Journal of Environmental Education, 34 (1), 9-15.

Nazir, M., \& Iram, S. (2001). A study of the scientific concepts of hearing impaired children of class $7^{\text {th }}$. (Unpublished master's thesis). University of the Punjab, Pakistan.

Noureen, A., \& Aziz, R. (2000). A study of interpersonal relationships between teachers and students in the institutions of hearing impaired children. (Unpublished master's thesis). University of the Punjab, Pakistan.

Ozdilek, Z., \& Ozkan, M. (2009). The effect of applying elements of instructional design on teaching material for the subject of classification of matter. The Turkish Online Journal of Educational Technology-TOJET, 8 (1). 84-96. Retrieved from http://eric. ed.gov/PDFS/ED503906.pdf. 
Ozsevgeç, T. (2006). Determining effectiveness of student guiding material based on the $5 \mathrm{E}$ model in "force and motion" unit. Journal of Turkish Science Education, 3 (2), 24-27. Retrieved from http://www.tused.org/internet/tused/archive/V3/i2/text/ tusedv3i2s3.pdf.

Patton, J. R., \& Andre, K. E. (1989). Individualizing for science and social studies. In J. Wood (Ed), Mainstreaming: A practical approach for teachers (pp. 301-351). Columbus, OH: Merrill.

Patton, J., Polloway, E., \& Cronin, M. (1990). A survey of special education teachers relative to science for the handicapped. (Unpublished manuscript). University of Hawaii, Honolulu.

Paul, P. V., \& Jackson, D. W. (1993). Towards a psychology of deafness. Boston: Allyn \& Bacon.

Quinsland, L. K. (1986). Experiential learning vs. lecture learning with postsecondary hearing-impaired learners: A study of the potential need for change to occur in instructional methodology (Doctoral Dissertation), Walden University.

Shah, A. M., \& Anjum, N. A. (2009). A study of general science concepts of students with hearing impairment at secondary level. (Unpublished master's thesis). University of the Punjab, Pakistan.

Shehbaz, F. S., Batool, B. S. (2008). A study of the perceptions of the teachers of hearing impaired children about the capabilities of hearing impaired children (Unpublished master's thesis). University of the Punjab.

Shoukat, N., \& Rubab, T. (2007). Comparative of study of scientific literacy of student with and without hearing (Unpublished master's thesis). University of the Punjab, Pakistan.

Sunal, C. S., \& Sunal, D. W. (1982). Adapting science for hearing impaired early adolescents (Final Report). Morgantown:West Virginia University. ERIC Document Reproduction Service No. ED 219267.

Wilsin, C., Taylor, J., Kowalski, S., \& Carlson, J. (2010). The relative effects of inquiry-based and commonplace science teaching on students' knowledge, reasoning and argumentation: A randomized control trial. Journal of Research in Science Teaching, 47 (3), 276 - 301. Retrieved from: http://www.bscs.org/pdf/BSCS_SREE_5E_presentation.pdf.

Zaleta, K. L. (2014). The effects of gender and type of inquiry curriculum on sixth grade students' science process skills and epistemological beliefs in science. Education Dissertations. 38. Retrieved from http://repository.wcsu.edu/cgi/viewcontent.cgi?artic le $=1039 \&$ context=educationdis. 